\title{
Community Perception of the Development of Productive Landscape in Yogyakarta City
}

\author{
Alia Bihrajihant Raya ${ }^{1 *}$, Siti Nurul Rofiqo Irwan², Retno Nur Utami ${ }^{3}$ and Ahmad Sarwadi ${ }^{4}$ \\ ${ }^{1}$ Department of Agricultural Socio-Economics, Faculty of Agriculture, Universitas Gadjah Mada, \\ Yogyakarta, Indonesia; ${ }^{2}$ Department of Agronomy, Faculty of Agriculture, Universitas Gadjah Mada, \\ Yogyakarta, Indonesia; ${ }^{3}$ Department of Forest Conservation, Faculty of Forestry, Universitas Gadjah Mada, \\ Yogyakarta, Indonesia; ${ }^{4}$ Department of Architecture, Faculty of Engineering, \\ Universitas Gadjah Mada, Yogyakarta, Indonesia \\ *Corresponding author: alia.bihrajihant.r@ugm.ac.id
}

\begin{abstract}
This research seeks to identify the potential of local community to support the development of productive landscape in Yogyakarta City. It hypothesizes the important roles of ecological perception, aesthetical perception, economics perception of productive plant, social-cultural perception, the role of social organization and the status of house ownership that would assist productive landscape development. This paper contributes to the importance of productive landscape development through community participation. The road/street location was chosen with purposive sampling by considering the characteristics of the arterial roads and local streets. Five arterial roads and five local streets were determined as the locations. The field survey method, with semi-structured questionnaires, was employed to obtain the primary data. The residences in arterial roads and local streets were selected by the linear systematic random sampling and the respondents participating in this study were 160 persons. The results have shown that the perception of residents depends on the experiences of their situation. The majority of residents have disclosed the low response on economical perception of productive landscape development in the greenery. The development of productive landscape is influenced by the ecological, aesthetical and socio-cultural perceptions of the residents living nearby the arterial roads. Meanwhile, the residents of local streets have a different perception of productive landscape development, which is influenced by ecological and aesthetical perceptions. The collaboration between government and community should be made to develop the efforts to grow and manage the vegetations along the roadsides of the city.
\end{abstract}

Keywords: community; landscape; perception; productive

Cite this as: Raya, A. B., Irwan, S. N. R., Utami, R. N., \& Sarwadi, A. (2020). Community Perception of the Development of Productive Landscape in Yogyakarta City. Caraka Tani: Journal of Sustainable Agriculture, 35(2), 239-249. doi: http://dx.doi.org/10.20961/carakatani.v35i2.32576

\section{INTRODUCTION}

Agriculture sector has a question to be answered, feeding over nine billion people in the world, meanwhile, at the same time, increasing the crop or production can also multiply the loss of biodiversity and proliferate gas emissions (McDougall et al., 2019). Gliessman (2012) concerns about the shifting paradigm of agriculture development, which does not only focus on the production but also its balance with environmental protection, economic opportunity and social equity for everyone. The sustainability of agriculture should be designed as a planning concept in economics, ecology and community self-reliance (Amin, 2010; Firth et al.,

\footnotetext{
* Received for publication July 20, 2019

Accepted after corrections April 22, 2020
} 
2011; Abbott, 2018).

In addition, socioeconomic, cultural and technological changes in the past century have driven the largest changes in our relationship to food and agriculture. Food production is not only about the farming but also about foodscape (Morgan and Sonnino, 2018). This term is related to urban agriculture, planning and urban studies, social science and public health, which refers to food environment, an alternative to food production and community behavior. Foodscape can also be defined as a communication device relating to the distribution, impact and relationship between people and food in a particular place (Mitchell and Heynen, 2013).

Based on the research of Roe et al. (2016), productive landscape character has been influenced by the evolving interactions between people and their habits, food and the specific location. Coinciding with the need to offer sustainable and productive city, it concerns with public open spaces, which are essential to the maintenance of health and natural resource (Napawan, 2006).

Productive urban landscape is outlined as two components of concept; the first concept focuses on the environmental design, which includes landscape architects and urban designer, while the second concept addresses the connection between ecological designers and policy-makers (Napawan, 2015). In order to employ productive landscape, the policy-makers need community participation for consideration (Johnson, 2012; Jerome, 2017). According to Wackernagel et al. (2006), productive landscape is the effort of cities and the inhabitants to manage their urban infrastructure towards the design of efficient and sustainable use of natural capital. Thus, the systems attached in the process of resource management present the particular opportunities to enhance the ecological aspect in urban areas by including the overlapping economic, social and environmental needs, which are lost due to the industrialization (Napawan and Burke, 2016). It is described that productive landscape is an urban space that provides food from urban agriculture, pollution absorption, the cooling effect of tress or increased biodiversity from wildlife (Kleszcz, 2018; McDougall et al., 2019).

The concept of urban productive landscape provides the sustainable balance of production and consumption. The impact of productive landscape would reinvent the three issues, which are environmentally productive, economically productive and socially productive (Amin, 2010). In addition, Guttmann-Bond (2014) declare that productive landscape is one of new perspectives of sustainable agriculture because it conserves the natural resources and avoids environmental pollution. Meanwhile, the sustainability of productive landscape can be focused on local economy to improve self-sustained production (Türky1lmaz et al., 2013).

The perception of landscape literature refers to how people and groups interpret the phenomena of environment and landscape in a more general way (Swaffield and Foster, 2000; Valenciasandoval et al., 2010; Abbott, 2018). Landscape depends on aesthetical and memory balance, perception and natural place (Menatti and Casado da Rocha, 2016). Perception does not only depend on the physical landscape but is also influenced by the values, past experience and socio-cultural background of a person (Scott, 2002). Moreover, the visualization of productive landscape should be able to enhance the social, aesthetic and economic performance for better perception of urban lifestyle (Bohn and Viljoen, 2011). Thus, perception is resulting subjectivity of human responses to particular landscape and people can give different opinion on the same scene. Involving residents in urban space planning is an essential aspect of sustainable city development (Brandão and Brandão, 2017), while managing the landscape will also work socially with habitants and encourage the uses of organic manure from the household waste that can create environmental benefit (Taiwo, 2011).

The problem is the majority of people in the community are not ready to take part in the decision making process and share the responsibility to maintain the green open space, but a group will perhaps show the interest to participate in productive landscape development (Kangur, 2015; Jerome, 2017). Meanwhile, the research about productive landscape in Indonesia especially in Yogyakarta Special Region has not been deployed. Based on the data from the Environment Agency of Yogyakarta in 2010, the productive landscape was defined as the public greenery open space, which was around $17.17 \%$ (557.90 ha) in Yogyakarta city. It is less than the number as stipulated by the regulation of Public Works, which is around 20\%. Even though the number of public green open spaces in Yogyakarta decrease, the private greenery open 
spaces increase above the national target (Budiman et al., 2014). In this case, Yogyakarta probably can increase the number of productive landscape by utilizing green open spaces, while the opportunity to develop the green open spaces is possibly made by functioning the community areas through empowering groups of women to manage gardens collectively. Suparwoko (2013) believes that Yogyakarta City will have more accessible productive landscape without any significant budget for purchasing the land because community can collaborate with the government.

Since the research of productive landscape development was limited, this present research seeks to identify the potential of local community to support productive landscape development in Yogyakarta City. The paper investigates how the local community accommodate the opportunity to build productive landscape in the neighborhood. It hypothesizes the important roles of ecological perception, aesthetical perception, economic perception of productive plants, social-cultural perception, the role of social organization and the status of house ownership to support productive landscape development. This paper contributes to the importance of productive landscape development through community. This study supports the literature in two stages. First, this study attempts to clarify the different factors that influence the development of productive landscape. Second, this study emphasizes that perceptions of ecology, aesthetic, economic function and socio-culture are the determinant factors of productive landscape development.

\section{MATERIALS AND METHOD}

This research was carried out in Yogyakarta City, Indonesia. The roads and street were chosen with purposive sampling by considering the characteristics of arterial roads and local streets based on the Decree of Yogyakarta Mayor Number 214/KEP/2013. Five arterial roads and five local streets were determined as the research locations representing the greenery open spaces in Yogyakarta City because of the number and types of trees in each area. The selected five arterial roads in Yogyakarta City were Jl. HOS Cokroaminoto (1), Jl. Kolonel Sugiyono (2), Jl. Tegal turi (3), Jl. AM Sangaji (4) and Jl. Mangkungbumi (5) while there were five local streets namely Jl. Patangpuluhan (6), Jl. Yomodipati (7), Jl. Tombol (8), Jl. Mayang (9) and Jl. Kompol Bambang Suprapto (10). The locations can be checked in Figure 1.

The field survey method with semi-structured questionnaires was applied to obtain the primary data. The residences in arterial roads or local streets were selected by using linear systematic random sampling. This type of sampling could be applied when population size was not exactly known (Elsayir, 2014). We randomly selected every $4^{\text {th }}$ residence in every arterial road until we had 16 respondents per arterial road. Since we selected five arterial roads, the total respondents of this study were 80 people. Simultaneously, we randomly selected $4^{\text {th }}$ residence in every local street until we had a respondent of $16^{\text {th }}$ and then we had 80 respondents living around five local streets. Thus, the total respondents were 160 persons.

The semi-structure questionnaires were used to obtain the data of dependent and independent variables. Dependent variable (Y) is the productive landscape development, while the independent variables are perception of ecology (X1), perception of aesthetic (X2), perception of economics (X3), the perception of socio-culture (X4), house ownership (X5-dummy) and the engagement to social organization (X5-dummy). The variable $\mathrm{Y}, \mathrm{X} 1, \mathrm{X} 2, \mathrm{X} 3$ and $\mathrm{X} 4$ were assessed using Likert scale. The validity of instrument was measured using Correlation Product Moment with 5\% level of significance, while the reliability of instrument was measured using Cronbach's Alpha. All variables had a Cronbach's Alpha coefficient more than 0.60 (high reliability).

The multiple linear regression was used to analyze the data. The result of analysis of residences on arterial roads and local streets were compared.

$$
\begin{gathered}
Y=A+b_{1} X_{1}+b_{2} X_{2}+b_{3} X_{3}+b_{4} X_{4}+b_{5} X_{5} \\
+b_{6} X_{6}+e
\end{gathered}
$$

Where:

$\mathrm{Y} \quad=$ Development of productive landscape

A $\quad=$ Constanta

$\mathrm{b}_{2}-\mathrm{b}_{5}=$ Coefficient

$\mathrm{X}_{1} \quad=$ Ecological perception

$\mathrm{X}_{2} \quad=$ Aesthetic perception

$\mathrm{X}_{3}=$ Economic perception 
$\mathrm{X}_{4} \quad=$ Socio-cultural perception

$\mathrm{X}_{6} \quad=$ Social organization-dummy

$\mathrm{X}_{5} \quad=$ House ownership-dummy

$\mathrm{e} \quad=$ Error

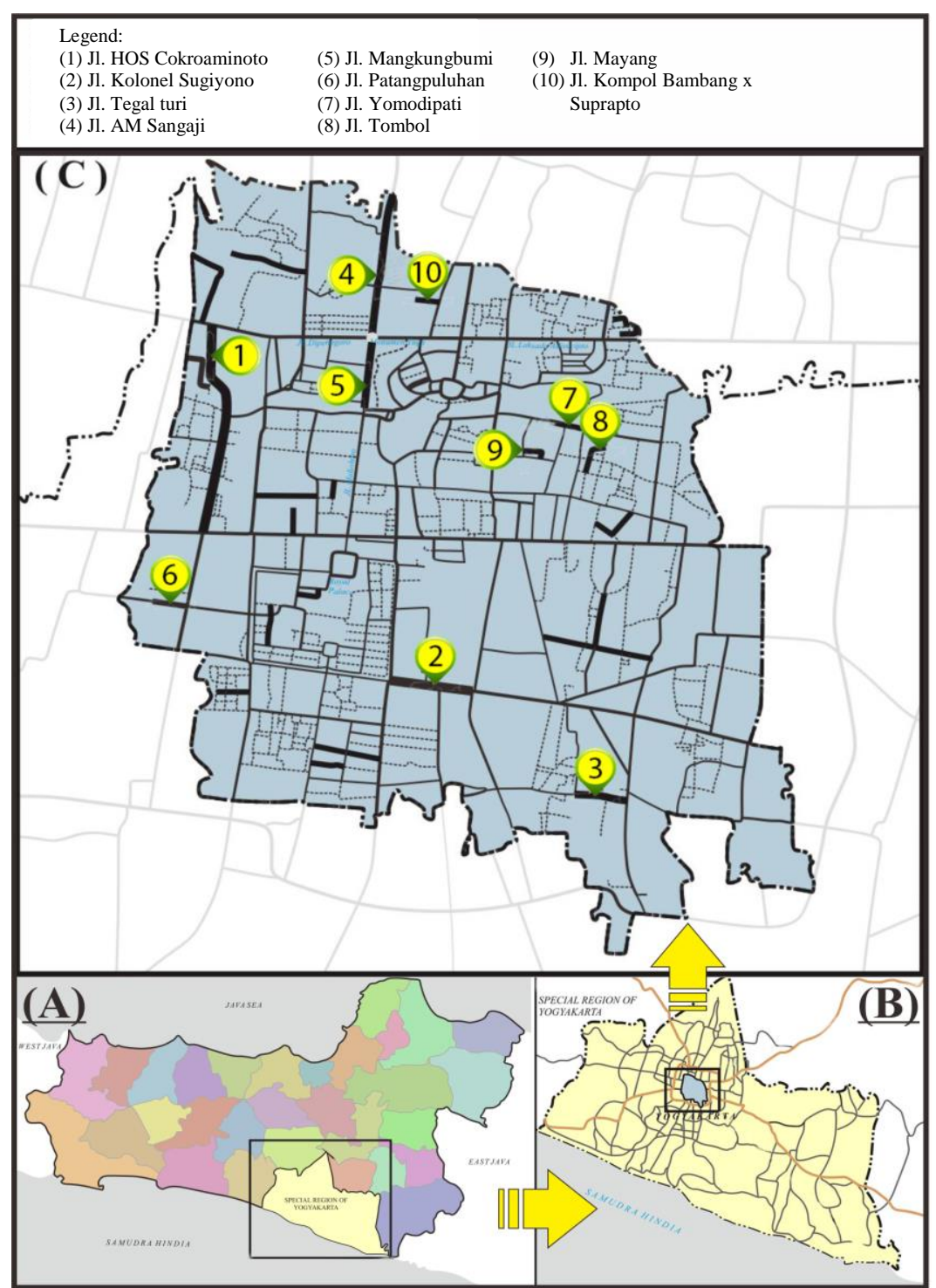

Figure 1. Research sites and locations of roads

Source: Secondary data analysis from Google Map (2019)

\section{RESULTS AND DISCUSSION}

The development of productive landscape has an important benefit in the urban ecosystem. Urban ecosystem includes residents who live either around arterial roads or local streets. Residents are the important aspect to take a lead on productive landscape development. The topdown approach is not adequate to drive the development of productive landscape (Scott, 2002). Table 1 presents the demographic data of respondents from arterial roads and local streets, which were categorized by age, educational background, house ownership and social organization.

Productive landscape is an emerging strategy integrating productivity through the landscape and planning of urban open space (Bohn and Viljoen, 2011). In this sense, urban space should be able to provide food from urban agriculture, help pollution absorption, improve the cooling effect of tress or increase biodiversity from wildlife. Green urban area is basically created by increasing the vegetation because asphalt and concrete could not retain water to improve humidity so that vegetation is important to support 
air movement and heat exchange (Bowler et al., 2010). Meanwhile, vegetation could be chosen due to its characteristics: it is edible and has economic value. The vegetation process, including growing, harvesting, trading and consuming, will become the responsibility of residents.

Development of productive landscape can affect people to choose where to live, how and where they work and their opinion of certain place. However, perception does not only depend on physical aspect but also deals with the values and socio-cultural condition. The responses to the landscape are the products of people interactions with physical and cultural environments. The planning system of the city landscape is the principal mechanism to facilitate individual need and public interest. Therefore, people can express the different perceptions of the same landscape. Engaging the residents in the planning of urban space is a key element of sustainable development, which can improve the quality of living. In order to gather the bottom-up information of productive landscape development of Yogyakarta City residents, the perception of ecology, aesthetic and socio culture are collected.

Table 1. Demographic data of residents on arterial roads and local streets

\begin{tabular}{|c|c|c|c|c|}
\hline \multirow{2}{*}{ Respondents characteristic } & \multicolumn{2}{|c|}{ Arterial road residents } & \multicolumn{2}{|c|}{ Local street residents } \\
\hline & Number of persons & $\%$ & Number of persons & $\%$ \\
\hline \multicolumn{5}{|l|}{ Age } \\
\hline$<30$ & 14 & 18 & 13 & 16 \\
\hline $31-40$ & 20 & 25 & 26 & 33 \\
\hline $41-50$ & 23 & 29 & 26 & 33 \\
\hline$>51$ & 23 & 29 & 15 & 19 \\
\hline Total & 80 & 100 & 80 & 100 \\
\hline \multicolumn{5}{|l|}{ Education } \\
\hline Elementary school & 4 & 5 & 8 & 10 \\
\hline Secondary school & 11 & 14 & 28 & 35 \\
\hline High school & 39 & 49 & 35 & 44 \\
\hline University & 26 & 33 & 9 & 11 \\
\hline Total & 80 & 100 & 80 & 100 \\
\hline \multicolumn{5}{|l|}{ House ownership } \\
\hline Householder & 47 & 59 & 59 & 74 \\
\hline Leaseholder & 33 & 41 & 21 & 26 \\
\hline Total & 80 & 100 & 80 & 100 \\
\hline \multicolumn{5}{|l|}{ Social organization } \\
\hline Joined & 60 & 75 & 59 & 74 \\
\hline Not joined & 20 & 25 & 21 & 26 \\
\hline Total & 80 & 100 & 80 & 100 \\
\hline
\end{tabular}

The indicators of aesthetic perception of greenery roadside include beautiful scenery, comfort space, creation of a good visual contrast of scenery, contribution to a good mood and the variety of plants. Table 2 demonstrates that the residents of local streets and arterial roads expect that aesthetic is an important factor on planning and designing landscape on greenery roadside. Aesthetic aspect on creating visual scenery by picking appropriate kind of trees to be planted on roadsides will increase the visualization of the Yogyakarta City.

Table 2. Perception of residents living along arterial roads and local streets about roadside greenery

\begin{tabular}{lcccc}
\hline \multirow{2}{*}{ Perception } & \multicolumn{2}{c}{ Arterial road residents $(\mathrm{N}=80)$} & \multicolumn{2}{c}{ Local street residents $(\mathrm{N}=80)$} \\
\cline { 2 - 5 } & Average score & Percentage & Average score & Percentage \\
\hline Perception of ecology & 2.48 & 57.11 & 2.66 & 61.37 \\
Perception of aesthetic & 3.07 & 65.80 & 3.43 & 73.50 \\
Perception of economics & 2.10 & 52.24 & 2.25 & 55.62 \\
Perception of socio-culture & 2.57 & 61.96 & 2.44 & 59.43 \\
\hline
\end{tabular}


Meanwhile, the residents' perception of ecology concerns on the reduction of air pollution, decrease in air velocity, provision of shelter of urban fauna and reduce noise. The resident of local street has a higher perception of ecology rather than residents on arterial road. In this case, the residents of arterial road probably have a problem with the street vegetation of roadside greenery in their daily life. Even though the vegetation around the arterial roads contribute to the reduction of pollution and noise, some damages occur. For instance, tree roots destroy the asphalts or pipes, as presented in Figure 2. In this sense, the ecological side does not only focus on the function of reducing pollution but also the safety of the environment and road users.

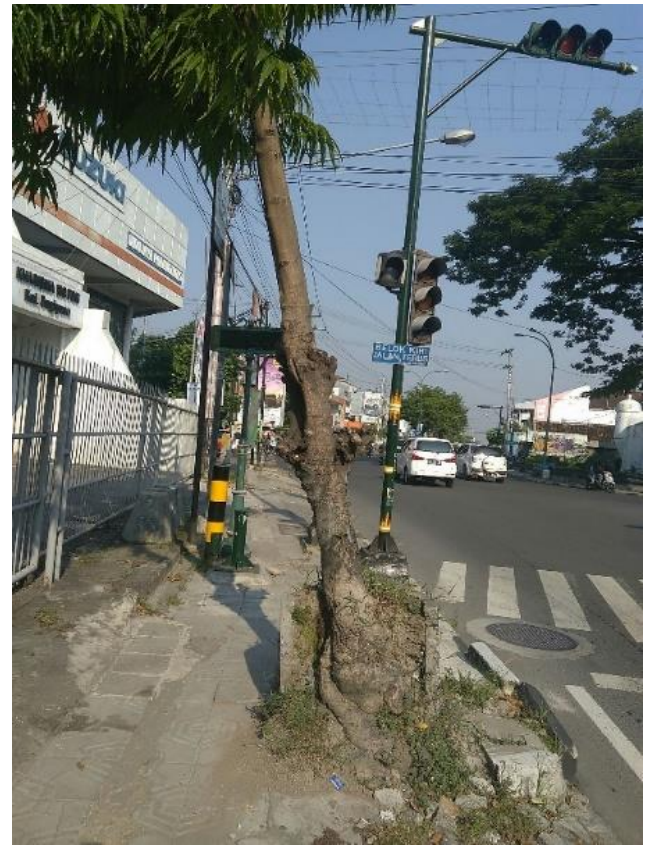

Figure 2. The damages of trees' roots

(Researchers' documentation, 2018)

On the other hand, the residents of arterial roads have a higher perception about socioculture. The perception of socio-culture is about the variety of plants symbolizing the territory and culture of Yogyakarta City. People believe that trees on the arterial roads for greenery should symbolize Yogyakarta City, as also reported by Cahya et al. (2017) that streets have become parts of the culture and tradition. Residents of local streets recognize that the trees should be easily managed. It is similar to the finding of research by Clapp (2010) that there was a linkage between the local residents and the trees on the green spaces.
However, some of them concern about the safety of people due to the accidents caused by abandoned fruits on the streets.

In order to understand the factors influencing productive landscape development of Yogyakarta Province, we conducted analyses of multiple linear regression (Table 3) to differ the factors of perception among the residents living in the areas around arterial roads and local streets. Based on the analyses, the ecological, aesthetic and sociocultural perceptions of the residents living in the areas along arterial roads significantly influence the productive landscape development. The residents consider that the ecological aspects, such as air circulation of arterial roads and local streets, should be improved. Pollution is a significant problem in this city because the functions of green spaces have decreased, as proven by the increasing pollution due to lead particles (Pb) (Damanik, 2014). Indonesia's Central Bureau of Statistics or Badan Pusat Statistik/BPS reported that the lead pollution in Yogyakarta was caused by the increasing number of motorcycles and other vehicles in 2004-2014, in which the increasing number of motor vehicle were around fourth times (BPSStatistics Indonesia, 2016).

Interestingly, the development of productive landscape cannot be affected by the perception of economics. Even though the productive landscape can give an economic benefit, the residents of arterial roads have a responsibility to manage and nurture the plants. Since the planning of productive landscape will occur in open fields and open green spaces of the streets, the residents are reluctant to get involved into it. Some of the residents argue that safety is the reason behind their decisions to not promote the productive plants in the city roadsides. As mentioned by Wolf (2010), there are some research findings on the relationships between roadside vegetations and accidents.

Communities' participation is essential to facilitate the groups of residents to keep plants, from growing, producing, harvesting until marketing. They assume that they will face difficulties in growing, producing and harvesting the plants. They also consider who will keep and enjoy the benefits of the products, as well as take the responsibilities to monitor the time for harvesting. The present research found that the residents' status on enganging the social 
organization put a negative influence on productive landscape development. This clearly shows that the community has diverse opinions about productive landscape management. They are reluctant to take the risks on the strategies to maintain and manage the vegetation. The community living along the arterial roads has never discussed about the division of the roles of local community and government in managing the vegetation in the roadsides.

Table 3. Multiple regression of productive landscape development

\begin{tabular}{lcccccc}
\hline \multirow{2}{*}{ Variable } & \multicolumn{2}{c}{ Residents of arterial roads } & \multicolumn{3}{c}{ Residents of local streets } \\
\cline { 2 - 7 } & Coefficient & Tcal & Sig & Coefficient & Tcal & Sig \\
\hline Perception of ecology $\left(\mathrm{X}_{1}\right)$ & $0.519^{* * *}$ & 4.742 & 0.000 & $0.469^{* * *}$ & 5.69 & 0.000 \\
Perception of aesthetic $\left(\mathrm{X}_{2}\right)$ & $0.193^{*}$ & 1.699 & 0.094 & $0.217^{* *}$ & 2.286 & 0.025 \\
Perception of economic $\left(\mathrm{X}_{3}\right)$ & -0.039 & -0.437 & 0.663 & 0.009 & 0.132 & 0.895 \\
Perception of socio-culture $\left(\mathrm{X}_{4}\right)$ & $0.467^{* *}$ & 2.378 & 0.019 & -0.077 & -0.675 & 0.502 \\
House ownership (Dummy- $\left.\mathrm{X}_{5}\right)$ & 1.313 & 1.28 & 0.205 & $-1.794^{*}$ & -1.858 & 0.067 \\
Social organization (Dummy- & $\left.-2.652^{* *}\right)$ & -2.33 & 0.023 & $-2.482^{* *}$ & -2.462 & 0.016 \\
\hline Constanta & 5.382 & & & 5.382 & & \\
\hline Number of observations & 80 & & & 80 & & \\
R square & 0.522 & & & 0.496 & & \\
Adjusted R square & 0.482 & & & 0.454 & & \\
F cal & 13.268 & & & 0.959 & & \\
F table & 0.363 & & & & & \\
\hline
\end{tabular}

90\% level of significance

Note: *Significant a $10 \%$ level; **Significant at $5 \%$ level; $* * *$ Significant at $1 \%$ level

The analyses also signify that the ecological and aesthetic perspectives of the residents living along local streets have vital influences on the productive landscape development. The residents argue that the roadsides should be developed to improve the air and water quality. As presented earlier, the number of motor vehicle keeps increasing and the noise pollution also follows the trail. Thus, they expect that the grenery and productive landscape development focus on noise reduction. The increasing number of motor vehicles also affects the availability of fresh air that influences the opportunity to create the social spaces for the community.

The community residing along local streets has an opportunity to make social contact more often than the residents of arterial roads because some of them do not work. Lee et al. (2015) have mentioned that green spaces can be used to facilitate social interaction while participation in community give a benefit for stress and anxiety alleviation and improve mood and attention of city residents. In addition, the residents nearby the local streets express that landscape refers to the beauty, naturalness and tidiness. The aesthetic perception deals with beautiful scenery, comfortable space, a good visual contrast of scenery, contribution to a good mood and the good variety of plants.

The development of productive landscape is influenced by good aesthetic perception. Meanwhile, the perception of socio-culture does not have any significant effect on the development of productive landscape. The historical and functional trees of Stelechocarpus burahol or kepel apple, favorite fruits of Javanese princesses in Yogyakarta Sultanate, are rarely planted on the areas of Yogyakarta City and most local residents have not tasted the fruits that produce high anti-oxidative compounds that are very useful when consumed (Ramadhan et al., 2016). Unfortunately, kepel apple trees are nearly extinct (Tisnadjaja et al., 2006) and therefore, conservation efforts are needed. This is inline with the results of the previous studies by Irwan and Sarwadi (2017) the local residents of Yogyakarta City have not paid attention on the historical trees, which symbolize the territory. Meanwhile, the tree that epitomizes Javanese culture, Ficus benjamina, is prohibited to be planted in the greenery roads because of the potential problems caused by its roots (Irwan et al., 2019).

The social structure and the status of house ownership have a significant negative effect on 
productive landscape development. The residents joining social groups and householders are skeptical to this landscape development. They explain that productive landscape will burden their life if the management of productive landscape is charged to the social organization because the government has not collaborated with them to arrange the greenery in the past. Moreover, they do not believe that they can enjoy any economic benefit when they grow edible plants in the public green spaces. Even though Bohn and Viljoen (2011) have revealed that developing urban farm will probably derive significant income and support to the local economy, but in reality, the residents of Yogyakarta City keep reluctant to get involved in it. The residents who join social organization have a negative perception about the development of productive landscape on the roadsides.

The residents of local streets and arterial roads also have the same consideration about the mechanism to manage landscape because social groups in the community have never discussed about the potential development of productive landscape. The consolidation and collaboration among the community, government and stakeholders should be made. According to Bohn and Viljoen (2011), the obstacles to develop productive landscape are land use policy to encounter the potential conflict among other forms of land use, the mechanism of financial returns for government to increase the Gross Domestic Product of the area and the technical and social obstacles. Productive landscape planning needs the participation of all residents to overcome the obstacles and conflicts. This research shows that community has not possessed the same understanding about how to organize green open spaces into good landscape and energy (food, material and so on). Moreover, some of them also arise the issue of the safety of food produced by the vegetations along the roadsides. Finally, it can be stated that public participation on the development of productive landscape is not only to obtain the perception on ecology, aesthetic, economics and socio-culture but also to improve the sense of participating in the community to synergize the roadside management.

\section{CONCLUSIONS}

The results of this research have revealed that the communities of Yogyakarta City, both who live around arterial roads and local streets, have a limited responses to the economical aspects. They still question whether greenery planted along the roadsides can provide self-sustained agricultural products for their consumption. The residents concern about the safety of fruits produced along the roadsides so that they hesitate to consume them. This research also found that the development of productive landscape can be influenced by the ecological, aesthetic and sociocultural aspects. Recently, the residents need good quality of air, less pollution and beautiful scenery in the roadsides, which are possible to get by planting and managing the vegetations as a development of productive landscape. The variety of fruits that will be planted should meet the criteria, uses, landscape values and history and rules on the formation concepts. Thus, it is necessary to well prepare the efforts to build the productive landscape in the Yogyakarta City neighborhood through policy and the improvement of community.

\section{ACKNOWLEDGEMENT}

This research was funded by the Ministry of Research, Technology and Higher Education of the Republic of Indonesia through PDUPT (Basic Research of Higher Education) scheme, 2018.

\section{REFERENCES}

Abbott, M. (2018). The sustaining beauty of productive landscapes. Journal of Landscape Architecture, 13(2), 8-19. https://doi.org/10. 1080/18626033.2018.1553389

Amin, A. M. (2010). Productive urban landscape: appropriating forces and criteria. Sustainable Architecture and Urban Development, III, 449-464. Retrieved from https://www. irbnet.de/daten/iconda/CIB_DC22690.pdf

Bohn, K., \& Viljoen, A. (2011). The edible city: envisioning the Continuous Productive Urban Landscape (CPUL). Field, 4(1), 149-161. Retrieved from https://www.researchgate.net/ publication/268393445_The_Edible_City_En 
visioning_the_Continuous_Productive_Urban _Landscape_CPUL

Bowler, D. E., Buyung-Ali, L., Knight, T. M., \& Pullin, A. S. (2010). Urban greening to cool towns and cities: A systematic review of the empirical evidence. Landscape and Urban Planning, 97(3), 147-155. https://doi.org/10. 1016/J.LANDURBPLAN.2010.05.006

BPS-Statistics Indonesia. (2016). Land transportation statistics 2016. Retrieved from https://www.bps.go.id/publication/2017/11/27 1500b5f875d5762ffb4e7a589/statistik-transpo rtasi-darat-2016.html

Brandão, A. L., \& Brandão, P. (2017). Public space, infrastructure, landscape: an interdisciplinary matrix for urban spatial continuity. The Journal of Public Space, 2(1), 123. https://doi.org/10.5204/jps.v2i1.55

Budiman, A., Sulistyantara, B., \& Zain, A. F. (2014). Detection of greenery open space change of five major cities in Java Island. Jurnal Lanskap Indonesia, 6(1), 7-15. Retrieved from https://journal.ipb.ac.id/index. php/jli/article/view/14074

Cahya, G. A., Mahendra, Y. K. D., \& Damanik, I. I. (2017). Malioboro as a value of Special District of Yogyakarta City. IOP Conference Series: Earth and Environmental, 70, 012055. https://doi.org/10.1088/1755-1315/70/1/0120 55

Clapp, A. (2010). Assessing the social impacts on urban street trees through the built environment in West Oakland, CA Angela Clapp. Semantic Scholar, (Spring), 1-18. Retrieved from https://pdfs.semanticscholar. org/c496/6724bbb9447ceca6ea72c1cfff27db0 d1dc5.pdf?_ga=2.153971633.844512871.158 7526327-351828619.1570846227

Damanik, F. (2014). Kajian komposisi jalur hijau jalan di Kota Yogyakarta terhadap penjerapan polutan timbal $(\mathrm{Pb})$. Planta Tropika: Journal of Agro Science, 2(2), 81-89. https://doi.org/ $10.18196 /$ pt.2014.027.81-89

Elsayir, H. A. (2014). Comparison of precision of systematic sampling with some other probability samplings. American Journal of Theoretical and Applied Statistics, 3(4), 111116. https://doi.org/10.11648/j.ajtas.2014030

\subsection{6}

Firth, C., Maye, D., \& Pearson, D. (2011). Developing "community" in community gardens. Local Environment, 16(6), 555-568. https://doi.org/10.1080/13549839.2011.5860 25

Gliessman, S. (2012). Agroecology and shifting paradigms. Journal of Sustainable Agriculture, 36(5), 499. https://doi.org/10. 1080/10440046.2012.684200

Guttmann-Bond, E. (2014). Productive lands capes: A global perspective on sustainable agriculture. Landscapes (United Kingdom), 15(1), 59-76. https://doi.org/10.1179/14662 03514Z.00000000024

Irwan, S. N. R., \& Sarwadi, A. (2017). Productive urban landscape in developing home garden in Yogyakarta City. IOP Conference Series: Earth and Environmental Science, 91, 012006. https://doi.org/10.1088/1755-1315/91/1/0120 06

Irwan, S. N. R., Utami, R. N., Sarwadi, A., \& Raya, A. B. (2019). Productive urban landscape through urban trees on roadside greenery of Yogyakarta City. Journal of Agronomy, 18(2), 61-70. https://doi.org/10.39 23/ja.2019.61.70

Jerome, G. (2017). Defining community-scale green infrastructure. Landscape Research, 42(2), 223-229. https://doi.org/10.1080/0142 6397.2016.1229463

Johnson, S. (2012). Reconceptualising gardening to promote inclusive education for sustainable development. International Journal of Inclusive Education, 16(5-6), 581-596. https: //doi.org/10.1080/13603116.2012.655493

Kangur, S. (2015). The importance of street trees - perception and preferences by urban residents [Thesis]. Estonian University of Life Sciences, Institute of Agriculture and Environment. Retrieved from https://dspace. emu.ee/xmlui/bitstream/handle/10492/2068/S igne_Kangur_Magistrit\%C3\%B6\%C3\%B6_2 015.pdf?sequence $=1 \&$ isAllowed $=\mathrm{y}$

Kleszcz, J. (2018). Urban farm as a system of productive urban green - challenges and risks. Architecture, Civil Engineering, Environment, 11(1), 23-36. https://doi.org/10.21307/acee- 


\section{8-003}

Lee, A. C. K., Jordan, H. C., \& Horsley, J. (2015). Value of urban green spaces in promoting healthy living and wellbeing: Prospects for planning. Risk Management and Healthcare Policy, 8, 131-137. https://doi.org/10.2147/ RMHP.S61654

McDougall, R., Kristiansen, P., \& Rader, R. (2019). Small-scale urban agriculture results in high yields but requires judicious management of inputs to achieve sustainability. Proceedings of the National Academy of Sciences of the United States of America, 116(1), 129-134. https://doi.org/10.1073/pnas .1809707115

Menatti, L., \& Casado da Rocha, A. (2016). Landscape and health: Connecting psychology, aesthetics, and philosophy through the concept of Affordance. Frontiers in Psychology, 7, 571. https://doi.org/10.3389/ fpsyg.2016.00571

Mitchell, D., \& Heynen, N. (2013). The geography of survival and the right to the city : speculations on surveillance, legal innovation, and the criminalization of intervention. Urban Geography, 30(6), 611-632. https://doi.org/ 10.2747/0272-3638.30.6.611

Morgan, K., \& Sonnino, R. (2018). The urban foodscape: World cities and the new food equation. Cambridge Journal of Regions Economy and Society, 3(2), 209-224. https://doi.org/10.1093/cjres/rsq007

Napawan, N. C. (2006). Multi-productive landscapes of the sustainable city: opportunities for managing resource needs through urban landscapes. 1-23. Retrieved from http://www.arch.chula.ac.th/nakhara/fil es/article/ROufgBjez9Wed84014.pdf

Napawan, N. C. (2015). Production places: Evaluating communally-managed urban farms as public space. Landscape Journal, 34(1), 3756. Retrieved from http://lj.uwpress.org/ content/34/1/37.abstract

Napawan, N. C., \& Burke, E. (2016). Productive potential: evaluating residential urban agriculture. Landscape Research, 41(7), 773779. https://doi.org/10.1080/01426397.2016.1 151487
Ramadhan, B. C., Aziz, S. A., \& Ghulamahdi, M. (2016). Potential bioactive content of kepel leaves (Stelechocarpus burahol). Buletin Penelitian Tanaman Rempah Dan Obat, 26(2), 99-108. Retrieved from https://www.research gate.net/publication/289540386_Potensi_kada r_bioaktif_yang_terdapat_pada_daun_kepel_ Stelechocarpus_burahol

Roe, M., Sarlöv Herlin, I., \& Speak, S. (2016). Identity, food and landscape character in the urban context. Landscape Research, 41(7), 757-772. https://doi.org/10.1080/01426397.2 016.1212324

Scott, A. (2002). Assessing public perception of landscape: The LANDMAP experience. Landscape Research, 27(3), 271-295. https:// doi.org/10.1080/01426390220149520

Suparwoko. (2013). Green open space approach to the building mass arrangement in Yogyakarta : Case study of the revitalization of the Tugu Rail Station. International Journal of Civil \& Environmental Engineering IJCEEIJENS, 13(4), 1-8. Retrieved from http:// ijens.org/Vol_13_I_04/130404-2727-IJCEEIJENS.pdf

Swaffield, S. R., \& Foster, R. J. (2000). Community perceptions of landscape values in the South Island high country. A literature review of current knowledge and evaluation of survey methods. In Science for Conservation, 159, 1-54. Retrieved from https://research archive.lincoln.ac.nz/handle/10182/1817

Taiwo, A. M. (2011). Composting as a sustainable waste management technique in developing countries. Journal of Environmental Science And Technology, 4(2), 93-102. http://dx.doi. org/10.3923/jest.2011.93.102

Tisnadjaja, D., Saliman, E., Silvia, S., \& Simanjutak, P. (2006). Study of burahol (Stelechocarpus burahol (Blume) Hook \& Thomson) as an antioxidative compounds containing fruit. Biodiversitas, 7(2), 199-202. https://doi.org/10.13057/biodiv/d070223

Türkyılmaz, Ç. C., Pellitero, A. M. M., Türkyılmaz, E., \& Eliziario, J. da S. (2013). Urban rehabilitation: Reinventing a productive landscape Istanbul, Golden Horn case study. International Journal of Architectural Research, 7(2), 282-296. 
Retrieved from https://archnet.org/publicati ons/7127

Valencia-sandoval, C., Flanders, D. N., \& Kozak, R. A. (2010). Planning participatory landscape planning and sustainable community development: Methodological observations from a case study in rural Mexico. Landscape and Urban Planning Journal, 94(1), 63-70. https://doi.org/10.1016/j.landurbplan.2009.07. 018

Wackernagel, M., Kitzes, J., Moran, D., Goldfinger, S., \& Thomas, M. (2006). The ecological footprint of cities and regions: comparing resource availability with resource demand. Environment and Urbanization, 18(1), 103-112. https://doi.org/10.1177/09562 47806063978

Wolf, K. L. (2010). Community Economics. - A Literature Review. In: Green Cities: Good Health (www.greenhealth.washington.edu). College of the Environment, University of Washington. Retrieved from https://depts. washington.edu/hhwb/Print_Economics.html 